\title{
TINJAUAN YURIDIS TINDAK PIDANA YANG DILAKUKAN OLEH ANAK DIBAWAH UMUR (Studi Kasus Putusan No.1/PID.SUS-Anak/2017/PN Mll)
}

Burhanuddin

Fakultas Hukum Universitas Andi Djemma Palopo

\begin{abstract}
Juridical Review of Crimes Conducted by Underage Children (Case Study of Decision No.1/PID.SUS-Anak/2017/PN Mll). In deciding cases of criminal acts committed by minors, the judge considers a juridical and non-juridical approach. Efforts and actions that can be carried out or attempted in resolving the case of a child who commits a crime without serving a prison sentence that is returned to parents and include him in the education program, guidance and guidance in government agencies or LPKS.
\end{abstract}

Keywords: Children, Crime, Prison

\section{A. PENDAHULUAN}

Anak merupakan bagian dari generasi muda yang merupakan penerus cita-cita perjuangan bangsa sekaligus merupakan modal sumber daya manusia bagi pembangunan nasional. Anak adalah generasi penerus bangsa yang mempunyai hak dan kewajiban ikut serta membangun negara dan bangsa Indonesia. Karena itu kualitas anak tersebut sangat ditentukan oleh proses dan bentuk perlakuan terhadap mereka dimasa kini. Anak Indonesia adalah manusia indonesia yang di besarkan dan dikembangkan sebagai manusia seutuhnya, sehingga mempunyai kemampuan untuk melaksanakan hak dan kewajiban sebagai warga negara yang rasional, bermanfaat dan bertangging jawab.

Anak Indonesia sebagai anak bangsa sebagian besar mempunyai kemampuan dalam mengembangkan dirinya untuk dapat melaksanakan hak dan kewajibannya sebagai warga negara yang bertanggung jawab dan bermanfaat untuk sesama manusia. Kondisi fisik dan mental seorang anak yang masih sangat lemah seringkali memungkinkan diinya disalahgunakan secara legal atau ilegal, secara langsung atau tidak langsung oleh orang-orang di sekelilingnya tanpa dapat berbuat sesuatu.

Kondisi buruk bagi anak ini, dapat berkembang secara terus-menerus dan mempengaruhi kehidupanya dalam keluarga, masyarakat dan negara. Situasi yang seperti ini dapat membahayakan negara, karena pada dasarnya maju atau mundurnya suatu bangsa sangat tergantung bagaimana bangsa itu mendidik anak-anaknya. Oleh karena itu, perlindungan anak perlu mendapatkan perhatian khusus didalam pembangunan bangsa. 
Anak perlu mendapat pelindungan dari dampak negatif perkembangan pembangunan yang cepat, arus globalisasi di bidang komunikasi dan informasi, kemajuan ilmu pengetahuan dan teknologi, serta perubahan gaya dan cara hidup sebagian orang tua yang telah membawa perubahan sosial yang mendasar dalam kehidupan masyarakat yang sangat berpengaruh terhadap nilai dan perilaku Anak. Penyimpangan tingkah laku atau perbuatan melanggar hukum yang dilakukan oleh Anak, antara lain, disebabkan oleh faktor dari dalam diri anak (keluarga) dan diluar diri Anak (lingkungan) tersebut. Oleh karena itu peranan orangtua untuk menjaga dan mendidik anak dalam perkembangan menuju kedewasaan menjadi kewajiban utama.

Sebelum anak-anak tumbuh dan berkembang menjadi dewasa, maka sebelumnya, terlebih dahulu anak-anak tersebut akan mengalami masa-masa atau dunia anak-anak. Selanjutnya dunia anak-anaklah yang akan membentuk dan mempersiapkan bagaimana proses pendewasaan nanti. Oleh karena itu, setiap anak perlu mendapatkan kesempatan yang seluas-luasnya untuk tumbuh dan berkembang secara optimal baik fisik, mental, sosial dan berakhlak mulia. Upaya perlindungan dan pembinaan terhadap anak perlu dilakukan dengan memberikan jaminan terhadap pemenuhan atas hak-haknya serta perlakuan tanpa diskriminasi.

Undang-Undang Nomor 23 Tahun 2002 tentang Perlindungan Anak menegaskan bahwa pertanggungjawaban orang tua, keluarga, masyarakat, pemerintah dan negara sangat perlu dilaksanakan secara terus-menerus demi terlindunginya hak-hak anak dan terbinanya anak-anak ke arah kehidupan yang terbaik bagi anak sebagai penerus bangsa yang potensial, tangguh, nasionalisme, berakhlak mulia, serta anak-anak berprilaku positif dan terhindar dari tindak keahatan atau perbuatan melawan hukum. Adapun hukuman atau pemidanaan yang dijatuhkan terhadap anak dibawah umur yang melakukan tindak pidana yang di atur dalam perundang-undangan ataupun dalam Kitab Undang-Undang Hukum Pidana (KUHP). Anak yang yang dikategorikan sebagai anak dibawah umur adalah bila anak tersebut belum berusia delapan belas (18) tahun.

Setiap anak memerlukan pembinaan dan perlindungan dalam rangka menjamin pertumbuhan dan perkembangan fisik, mental dan social secara utuh, serasi, selaras dan seimbang. Pembinaan dan perlindungan anak ini tak mengecualikan pelaku tindak pidana anak, yang kerap disebut sebagai anak nakal.Selama ini, penanganan perkara pidana yang pelakunya masih tergolong anak dibawah umur, dapat dikatakan hampir sama penanganannya dengan perkara-perkara pidana yang pelakunya adalah orang dewasa.

Hal yang transparan dalam proses pemeriksaan terhadap anak, adalah apabila terhadap tersangka anak tersebut dilakuan penahanan, dari segi waktu tidak berbeda dengan waktu penahanan yang berlaku bagi orang dewasa. Begitu pula petugas pemeriksa dalam memeriksa tersangka anak-anak dilakukan dengan cara yang sama dengan orang dewasa. Selain itu, karena kamar tahanan tidak mencukupi, maka terpaksa di campur, dengan pelaku 
tindak pidana dewasa. Tindakan pencampuran ini kurang bijaksana, karena anak-anak tersebut dapat menimba modus operandinya.

Ditinjau dari aspek yuridis maka pengertian "Anak" dimata hukum positif Indonesia Lazim diartikan sebagai orang yang belum dewasa (minderjaring/person under age), orang yang dibawah umur atau keadaan dibawah umur (minderjarigheid/inferiority) atau kerap disebut sebagai anak yang dibawah pengawasan wali (minderjarige ondervoordij)1. Pengertian anak itu sendiri jika kita tinjau lebih lanjut dari segi usia kronologis menurut hukum dapat berbeda-beda tergantung tempat, waktu dan untuk keperluan apa, hal ini juga akan mempengaruhi batasan yang digunakan untuk menentukan umur anak.

Penjatuhan sanksi merupakan alat kekuasaan untuk menguatkan berlakunya suatu norma dan untuk mencegah serta memberantas tindakantindakan yang mengganggu berlakunya suatu norma. Tujuan yang ingin dicapai dari penjatuhan sanksi terhadap anak adalah agar anak tersebut dapat berbaur kembali terhadap masyarakat. Double track system merupakan sistem dua jalur mengenai sanksi dalam hukum pidana, yaitu sanksi pidana dan jenis sanksi tindakan. Sekalipun dalam prakteknya, perbedaan antara sanksi pidana dan sanksi tindakan sering agak samar, namun di tingkat ide dasar keduanya memiliki perbedaan mendasar, dimana sanksi pidana bersumber pada ide dasar "mengapa diadakan pemidanaan", sedangkan sanksi tindakan bertolak dari ide dasar "untuk apa diadakan pemidanaan itu"

Mengingat ciri dan sifat yang khas pada Anak dan demi pelindungan terhadap Anak, perkara Anak yang berhadapan dengan hukum wajib disidangkan di pengadilan pidana Anak yang berada di lingkungan peradilan umum. Proses peradilan perkara Anak sejak ditangkap, ditahan, dan diadili pembinaannya wajib dilakukan oleh pejabat khusus yang memahami masalah Anak.

Jika harus dilakukan proses hukum terhadap anak maka tentunya kurang adil jika kepada terdakwa anak diberlakukan proses hukum yang sama dengan terdakwa dewasa. Begitu juga dengan pidana yang nantinya akan dijatuhkan kepada anak, tentunya sangat tidak adil jika pidana yang harus dijalani sama dengan pidana terdakwa dewasa. Apalagi mengingat bahwa anak merupakan penerus cita-cita perjuangan bangsa, sehingga dalam menanangani tindak pidana yang dilakukan oleh anak, harus betul-betul memperhatikan kepentingan dan masa depan anak.

Oleh karena itu, melalui Pasal 103 Kitab Undang-Undang Hukum Pidana, masih dibenarkan adanya perbuatan lain yang menurut undang-undang selain KUHP dapat dipidana sepanjang undang-undang itu bertalian dengan masalah anak dan tidak bertentangan dengan ketentuan Kitab Undang-Undang Hukum Pidana (lex specialis derogat legi generali).

Melalui asas ini pula hukum pidana anak membenarkan undang-undang lain, di luar Kitab Undang-Undang Hukum Pidana yang bertalian dengan masalah anak seperti Ketentuan hukum yang diatur dalam Undang-Undang Nomor 11 Tahun 2012 Tentang Sistem Peradilan Pidana Anak, di dalam 
undang-undang ini mengatur pembedaan perlakuan di dalam hukum acara maupun ancaman pemidanaannya.

Pembedaan perlakuan dan ancaman yang diatur dalam undang-undang ini dimaksudkan untuk lebih memberikan perlindungan dan pengayoman terhadap anak dalam menyongsong masa depannya yang masih panjang. Selain itu, pembedaan tersebut dimaksudkan untuk memberikan kesempatan kepada anak agar setelah melalui pembinaan akan memperoleh jati dirinya untuk menjadi manusia yang lebih baik, yang berguna bagi diri, keluarga, masyarakat, bangsa dan negara.

Berkaitan dengan hal tersebut di atas yang dalam kenyataan hakim dalam menjatuhkan putusan kadang-kadang tidak sesuai dengan peraturan perundang-undangan yang berlaku. Akibatnya dapat merugikan bagi diri si pelaku, terutama dalam menjatuhkan putusan terhadap anak yang seharusnya mendapatkan perlindungan dan perhatian khusus untuk terus tumbuh dan berkembang sebagai generasi penerus bangsa, dalam konteksnya sering dianggap tidak adil bagi anak.

Undang-Undang Nomor 3 Tahun 1997 Pengadilan Anak ternyata juga telah mencabut ketentuan Pasal 45, 46, dan Pasal 47 (Kitab Undang-Undang Hukum Pidana (KUHP), yang selama ini digunakan dalam menangani perkara anak. Sehingga saat ini, ketentuan-ketentuan tersebut sudah tidak berlaku lagi. Selain itu dalam Ketentuan Mahkamah Konstitusi Nomor 1/PUU-VIII/2010 atas perubahan Undang-Undang Nomor 3 Tahun 1997 Tentang Pengadilan Anak, dengan pertimbangan hukum, anak dapat dikategorikan sebagai anak nakal, bukan merupakan proses tanpa prosedur dan dapat dijustifikasi oleh setiap orang.

Pemberian kategori anak nakal merupakan justifikasi yang dapat dilakukan melalui sebuah proses peradilan yang standartnya akan ditimbang serta dibuktikan dimuka hukum. Dengan adanya perubahan tersebut, maka diharapkan penanganan perkara anak sudah dapat dibedakan dengan perkara orang dewasa demi perkembangan psikologis anak serta kepentingan dan kesejahteraan masa depan anak.

Dalam meminimalisir kasus yang merugikan anak, Negara/Pemerintah telah berupaya memberi perhatiannya dalam wujud Undang-UndangNomor 23 Tahun 2002 Tentang Perlindungan Anak, namun hal tersebut belum mampu menekan peningkatan kuantitas dan kualitas kasus yang melibatkan anak baik sebagai korban maupun pelaku tindak pidana. Untuk menyikapi hal itu, maka Negara/Pemerintah, telah merumuskan suatu peraturan perundang-undangan baru, yaitu Undang-Undang Nomor 11 Tahun 2012 tantang Sistem Peradilan Pidana Anak yang akan diberlakukan untuk mengatasi dan menyelesaikan perkara tindak pidana yang dilakukan oleh anak. Dengan adanya dan akan berlakunya Undang-Undang Nomor 11 Tahun 2012 tantang Sistem Peradilan Pidana Anak tersebut diharapkan dapat lebih tepat dan optimal dalam menangani serta menyelesaikan perkara anak yang melakukan tindak pidana.

Berkaitan dengan penahanan kasus-kasus yang melibatkan anak telah dilakukan berbagai upaya untuk menyelamatkan anak yang berkonflik dengan 
hukum diantaranya dengan adanya kesepakatan bersama dalam penanganan penanganan kasus anak bermasalah dengan hukum melalui Surat Keputusan Bersama (SKB) tanggal 22 Desember 2009, antara Mentri Hukum dan HAM, Menteri Pemberdayaan Perempuan dan Perlindungan Anak, Menteri Sosial, JaksaAgung, Kepolisian RI serta Mahkamah Agung Tentang Penanganan Anak Yang Berhadapan Dengan Hukum. Adapun Surat Keputusan Bersama (SKB) tersebut menyatakan:

a. Bahwa anak sebagai generasi penerus bangsa berhak memperoleh perlindungan baik secara fisik, mental, maupun sosial sehingga anak dapat tumbuh dan berkembang secara sehat dan wajar termasuk anak yang berhadapan dengan hukum;

b. Bahwa penanganan anak yang berhadapan dengan hukum oleh aparat penegak hukum belum menunjukkan kemajuan yang signifikan dalam peraturan perlindungannya sesuai dengan peraturan perundangundangan;

c. Bahwa untuk meningkatkan penanganan anak yang berhadapan dengan hukum sesuai dengan peraturan perundang-undangan sebagaimana dimaksud dalam huruf $b$, perlu kerja sama yang terpadu antar penegak hukum dalam pelaksanaan sistem peradilan pidana terpadu untuk pemenuhan kepentingan terbaik bagi anak;

d. Bahwa pendekatan keadilan restoratif perlu dijadikan sebagai landasan pelaksanan sistem peradilan pidana terpadu bagi anak yang berhadapan dengan hukum;

e. Bahwa berdasarkan pertimbangan sebagaimana dimaksud dalam huruf a, huruf b, huruf c, dan huruf d perlu menetapkan Keputusan Bersama Ketua Mahkamah Agung Republik Indonesia, Jaksa Agung Republik Indonesia, Kepala Kepolisian Negara Republik Indonesia, Menteri Hukum dan Hak Asasi Manusia Republik Indonesia, Menteri Sosial Republik Indonesia, dan Menteri Negara Pemberdayaan Perempuan dan Perlindungan Anak Republik Indonesia;.

Pidana penjara dapat memberikan stigma yang akan terbawa terus walaupun yang bersangkutan tidak melakukan kejahatan lagi. Akibat penerapan stigma bagi anak akan membuat merekasulit untuk kembali menjadi anak "baik".

\section{B. METODE PENELITIAN}

Jenis Penelitian dalam penulisan ini adalah Yuridis Empiris. Yang dimaksud yuridis empiris ialah pendekatan permasalahan mengenai hal-hal yang bersifat yuridis dan kenyataan yang ada mengenai pelaksanaan didasarkan atas fakta-fakta yang diperoleh dari hasil penelitian dan observasi. Lokasi penelitian ini adalah di Pengadilan Negri Luwu Timur yang terletak di Kota Malili Kabupaten Luwu Timur. 
Data yang diperoleh dan dikumpulkan baik dalam primer maupun data sekunder dianalisis secara kualitatif yaitu suatu cara penelitian yang dilakukan guna mencari kebenaran kualitatif.

\section{HASIL PENELITIAN}

\section{Dasar pertimbangan Hakim dalam menjatuhkan sanksi pidana penjara} terhadap anak dibawah umur.

Pertimbangan hakim merupakan salah satu aspek terpenting dalam menentukan terwujudnya nilai dari suatu putusan hakim yang mengandung keadilan (ex aequo et bono) dan mengandung kepastian hukum, di samping itu juga mengandung manfaat bagi para pihak yang bersangkutan sehingga pertimbangan hakim ini harus disikapi dengan teliti, baik, dan cermat. Apabila pertimbangan hakim tidak teliti, baik, dan cermat, maka putusan hakim yang berasal dari pertimbangan hakim tersebut akan dibatalkan oleh Pengadilan Tinggi Mahkamah Agung (Mukti Arto : 2004 : 140).

Dalam pemeriksaan suatu perkara juga memerlukan adanya pembuktian, dimana hasil dari pembuktian itu akan digunakan sebagai bahan pertimbangan dalam memutus perkara. Pembuktian merupakan tahap yang paling penting dalam pemeriksaan di persidangan. Pembuktian bertujuan untuk memperoleh kepastian bahwa suatu peristiwa / fakta yang diajukan itu benar-benar terjadi, guna mendapatkan putusan hakim yang benar dan adil. Hakim tidak dapat menjatuhkan suatu putusan sebelum nyata baginya bahwa peristiwa / fakta tersebut benar-benar terjadi, yakni dibuktikan kebenaranya, sehingga nampak adanya hubungan hukum antara para pihak. (Mukti Arto : 2004 : 141).

Dasar hakim dalam menjatuhkan putusan pengadilan perlu didasarkan kepada teori dan hasil penelitian yang saling berkaitan sehingga didapatkan hasil penelitian yang maksimal dan seimbang dalam tataran teori dan praktek. Salah satu usaha untuk mencapai kepastian hukum kehakiman, di mana hakim merupakan aparat penegak hukum melalui putusannya dapat menjadi tolak ukur tercapainya suatu kepastian hukum.Seorang hakim diwajibkan untuk menegakkan hukum dan keadilan dengan tidak memihak. Hakim dalam memberi suatu keadilan harus menelaah terlebih dahulu tentang kebenaran peristiwa yang diajukan kepadanya kemudian memberi penilaian terhadap peristiwa tersebut dan menghubungkannya dengan hukum yang berlaku. Setelah itu hakim baru dapat menjatuhkan putusan terhadap peristiwa tersebut. Seorang hakim dianggap tahu akan hukumnya sehingga tidak boleh menolak memeriksa dan mengadili suatu peristiwa yang diajukan kepadanya.

Berhubungan dengan hal tersebut, dalam perkara tidak pidana sebagaimana yang disebutkan dalam Putusan Pengadilan Negeri Malili No. No.1/PID.SUS-Anak/2017/PN Mll terdapat beberapa pertimbangan hakim dalam menjatuhkan pidana penjara terhadap anak dibawah umur, sebagaimana yang yang telah diuraikan oleh Hakim Pengadilan Negeri Malili yang peneliti temui yang bernama RENO HANGGARA, SH. Beliau mengatakan: 
Dalam memutus perkara, hakim mempertimbangkan secara yuridis dan non yuridis, hal-hal yudiris diantaranya adalah terpenuhinya unsur-unsur pasal yang didakwakan, keterangan saksi, keterangan terdakwa, dan barang bukti. Sedangkan pertimbangan non yuridis diantaranya latar belakang perbuatan terdakwa, akibat perbuatan terdakwa, kondisi diri terdakwa, keadaan sosial ekonomi terdakwa. Dalam hal perkara anak hakim sangat mempertimbangkan bahwa anak adalah generasi penerus bangsa yang diharapkan mampu untuk merubah diri dalam perjalanannya menjalani hukuman yang diberikan.

Lebih lanjut, RENO HANGGARA menjelaskan:

Untuk perkara tindak pidana dalam Putusan Pengadilan Negeri Malili No. No.1/PID.SUS-Anak/2017/PN Mll, hakim memutuskan untuk memberi pidana terhadap MA yakni penjara 4 tahun dengan pertimbangan unsur-unsur pasal yang disangkakan telah terpenuhi, sedangkan hal lain yang menajdi pertimbangan adalah pelaku merupakan anak dibawah umur sehingga hukumannya dibedakan dari orang dewasa.

Dari penjelasan Hakim Pengadilan Negeri Malili tersebut, terlihat bahwa dalam memutus perkara pidana pada anak hakim memiliki pertimbangan sebagai berikut :

1. Pertimbangan Yuridis, adalah pertimbangan hakim yang didasarkan pada fakta-fakta yuridis yang terungkap didalam persidangan dan oleh undangundang telah ditetapkan sebagai hal yang harus dimuat di dalam putusan. Pada tulisan ini, yang dimaksudkan tersebut diantaranya adalah: Dakwaan jaksa penuntut umum, keterangan terdakwa dan saksi, barang-barang bukti, pasal-pasal dalam peraturan hukum pidana dan lain sebagainya.

2. Pertimbangan Non-Yuridis. Didalam memutus sebuah perkara dan mempertimbangkan layak tidaknya seseorang dijatuhi pidana seorang hakim didasarkan oleh keyakinan hakim dan tidak hanya berdasarkan bukti-bukti yang ada, tetapi juga mempertimbangkan keadaan-keadaan yang digolongkan sebagai pertimbangan yang bersifat nonyuridis seperti : latar belakang perbuatan terdakwa, akibat perbuatan terdakwa, kondisi diri terdakwa, keadaan sosial ekonomi terdakwa.

Dalam hal perkara tindak pidana yang telah diputus dalam Putusan Pengadilan Negeri Malili NO. 1/PID.SUS-Anak/2017/PN Mll tersebut, hakim memutus terdakwa terbukti bersalah secara sah dan meyakinkan melakukan tindak pidana sebagaimana dalam pasal 170 ayat (2) ke-3 Kitab UndangUndang Hukum Pidana Jo Undang-Undang Nomor 11 Tahun 2012 tentang Peradilan Anak, eleh karena itu dijatuhi hukuman empat (4) tahun penjara dipotong masa tahanan selama terdakwa dalam proses hukum.

Menurut peneliti, putusan hakim tersebut sudah tepat karena telah memenuhi syarat yuridis yaitu : terpenuhinya unsur dalam pasal 170 ayat (2) ke-3 yakni: 
Barang siapa dengan terang-terangan dan tenaga bersama-sama menggunakan kekerasan terhadap orang atau barang yang mengakibatkan mau.

Selain hal tersebut, adanya keterangan (pengakuan) terdakwa dimuka persidangan membenarkan tentang perbuatan yang dilakukannya bersama empat orang rekannya yang lain. keterangan saksi dan barang bukti yang ditemukan berupa : satu (1) buah kayu yang berbetuk papan dengan ukuran panjang 116 (seratus enam belas) cm dan lebar 13 (tiga belas) cm, satu (1) buah potongan bambu dengan ukuran panjang 60 (enam puluh) $\mathrm{cm}, 10$ (sepuluh) buah pecahan bambu yang terdapat noda darah, selain itu visum et repertum No. : VER/51/VER/RSUD/ILG/LT XII/2016 pada tanggal 16 Desember 2016 dengan kesimpulan : luka yang dialami korban adalah luka robek yang disebabkan oleh karena trauma benda tajam.

Sedangkan pertimbangan non yuridisny adalah keadaan-keadaan diantaranya :

1. Hal-hal yang memberatkan, seperti :

a. Perbuatan terdakwa meresahkan masyarakat.

b. Perbuatan terdakwa telah meninggalkan luka yang mendalam pada keluarga korban.

2. Hal-Hal yang meringankan :

a. Terdakwa belum pernah dihukum.

b. Terdakwa menyesali perbuatannya.

c. Terdakwa masih muda sehingga diharapkan masih dapat memperbaiki sikap dan tingkah lakunya dimasa akan datang.

2. Upaya-upaya serta tindakan-tindakan lain yang dapat dilakukan atau diusahakan dalam menyelesaikan perkara anak yang melakukan tindak pidana, tanpa harus menjalani hukuman penjara.

Anak merupakan aset bangsa, sebagai bagian dari generasi muda anak merupakan penerus yang strategis sebagai suksesi suatu bangsa. Dalam konteks Indonesia, anak adalah penerus cita-cita perjuangan bangsa. Peran strategis ini telah disadari oleh masyarakat Internasional untuk melahirkan sebuah konvensi yang menekankan posisi anak sebagai makhluk manusia yang harus mendapatkan perlindungan atas hak-hak dasar yang dimilikinya.

Melindungi anak adalah amanat konstitusi, yang secara progresif menyebutkan hak konstitusional anak dalam Pasal 28 B ayat (2) UUD 1945 berbunyi: "Setiap anak berhak atas kelangsungan hidup, tumbuh dan berkembang serta berhak atas perlindungan yang layak".

Pembinaan dan perlindungan terhadap anak di hadapkan pada permasalahan dan tantangan dalam masyarakat yang terkadang dijumpai penyimpangan perilaku di kalangan anak-anak dan perbuatan yang melanggar hukum tanpa memandang status sosial dan ekonomi di samping itu terdapat pula anak yang karena salah satu hal, tidak mempunyai kesempatan untuk berkembang baik secara mental, fisik maupun sosial, karena keadaan tersebut 
sering kali terjadi maupun tidak, anak melakukan tindakan atau perilaku yang dapat merugikan dirinya sendiri atau masyarakat dalam menaggulangi berbagai perbuatan dan tingkah laku anak yang melanggar hukum, perlu dipertimbangkan keadaan anak dalam segala kharakter, ciri dan sifat yang khas.

Walaupun anak telah dapat menentukan sendiri arah langkah perbuatannya berdasarkan pikiran, perasaan dan kehendaknya, tetapi kondisi lingkungan dapat mempengaruhinya. Oleh karena itu dalam menanggulangi kasalahan anak yang melakukan perbuatan melanggar hukum, maka orang tua, masyarakat dan aparat penegak hukum seharusnya lebih mengarah pada pembinaan, pendidikan dan pengembangan parilaku anak, sehingga diperlakuan aparat penegak hukum dalam penegakan hukum terhadap anak yang demikian perlu memperhatikan perlindungan hukum terhadap anak. Untuk mewujudkan perlindungan hukum terhadap anak yang melakukan perbuatan yang melanggar hukum, aparat penegak hukum pada berbagai lembaga yang terkait dalam proses peradilan harus berpegang pada peraturan hukum yang berlaku sesuai Undang-undang Perlindungan Anak No. 22 Tahun 2003.

Setiap anak memerlukan pembinaan dan perlidungan dalam rangka menjamin pertumbuhan dan perkembangan fisik, mental dan sosial secara utuh, serasi, selaras dan seimbang. Berkaitan dengan anak yang melakukan perbuatan pidana sehingga harus dijatuhkan ke sidang pengadilan anak, perbuatan pidana yang dilakukan oleh anak-anak adalah sejenis dengan perbuatan yang dilakukan oleh orang dewasa. Yang membedakan adalah pelakunya, yakni anak-anak. Pengetahuan ini sangat penting untuk diketahui oleh pejabat-pejabat yang bersangkutan dengan anakanak yang melakukan perbuatan melanggar hukum atau melakukan tindak pidana.

Tujuan diberikannya perlindungan hukum bagi pelaku kejahatan anak dan ketika anak di hadapkan dengan hukum adalah untuk menghormati hak asasi si pelaku agar nasibnya tidak terkatung-katung, adanya kepastian hukum bagi pelaku serta menghindari perlakuan sewenang-wenang dan tidak wajar. Sedangkan konsepsi perlindungan anak meliputi ruang lingkup yang luas, dalam arti bahwa perlindungan anak tidak hanya mengenai perlindungan atas jiwa dan raga anak, tetapi mencakup pula perlindungan atas semua hak serta kepentingannya yang dapat menjamin pertumbuhan secara wajar, baik secara rohani, jasmani maupun sosialnya sehingga diharapkan dapat menjadi orang dewasa yang mampu berkarya (Wagiati Soetodjo. 2006: 164).

Penerapan sanksi terhadap anak harus mempertimbangan kepentingan terbaik bagi anak dalam proses penegakan hukum. Salah satunya dengan menggunakan alternatif hukuman lain selain pidana formal, seperti :

1. Menyerahkannya kembali kepada orang tua/Wali. Misalnya dengan mengembalikan kepada orangtua diharapkan anak dapat dididik dan bina untuk menjadi pribadi yang lebih baik, terlebih ketiak anak menyesali perbuatannya. Pengembalian anak kepada orang tua diharapkan mampu 
member pembinaan terhadap anak agar memiliki masa depan yang lebih baik.

2. Mengikutsertakannya dalam program pendidikan, pembinaan, dan pembimbingan di instansi pemerintah atau LPKS.

Undang-Undang Nomor 11 Tahun 2012 tentang Sistem Peradilan Pidana Anak mengamanatkan Kementerian Sosial melaksanakan rehabilitasi sosial bagi anak yang berhadapan dengan hukum melalui lembaga penyelenggaraan kesejahteraan sosial. Untuk itu, Menteri Sosial Khofifah Indar Parawansa pada 15 Juni 2015 telah menerbitkan Peraturan Menteri Sosial (Permensos) Nomor 9 Tahun 2015 tentang Pedoman Rehabilitasi Sosial Anak yang Berhadapan dengan Hukum oleh Lembaga Penyelenggaraan Kesejahteraan Sosial. Permensos itu menyebutkan, pedoman rehabilitasi sosial anak yang berhadapan dengan hukum $(\mathrm{ABH})$ oleh Lembaga Penyelenggaraan Kesejahteraan Sosial (LPKS) bertujuan memberikan arah dan pedoman kerja bagi pemerintah, pemerintah daerah, aparat penegak hukum, LPKS ABH, dan masyarakat, terlaksananya proses rehabilitasi sosial di dalam LPKS $\mathrm{ABH}$, memberikan perlindungan $\mathrm{ABH}$ oleh LPKS, dan meningkatnya kualitas rehabilitasi sosial ABH.

Rehabilitasi sosial $\mathrm{ABH}$ ditujukan kepada anak yang belum berusia dua belas tahun melakukan tindak pidana atau di duga melakukan tindak pidana, anak yang sedang menjalani proses hukum ditingkat penyidikan, penuntutan, dan pengadilan, anak yang telah mendapatkan penetapan diversi, atau anak yang telah mendapatkan penetapan dan/atau putusan pengadilan yang memiliki kekuatan hukum tetap. Rehabilitasi sosial $\mathrm{ABH}$ bertujuan agar $\mathrm{ABH}$ dapat melaksanakan fungsi sosialnya. Ini meliputi kemampuan dalam melaksanakan peran, memenuhi hak-hak anak, memecahkan masalah, aktualisasi diri, dan pengembangan potensi diri, dan tersedianya lingkungan sosial yang mendukung keberhasilan Rehabilitasi Sosial ABH.

Peraturan itu juga menyebutkan, rehabilitasi sosial ABH dapat dilakukan di dalam LPKS dan/atau di luar LPKS. LPKS merupakan lembaga yang telah ditetapkan oleh Menteri Sosial. Bentuk kegiatan rehabilitasi sosial oleh LPKS antara lain motivasi dan diagnosis psikososial, perawatan dan pengasuhan, pelatihan vokasional dan pembinaan kewirausahaan, bimbingan mental spiritual, bimbingan fisik, bimbingan sosial, konseling psikososial, dan kegiatan lainnya.

Intervensi bagi pelaku tidak perlu melalui proses formal sehingga anak terhindar dari proses sistem peradilan. Bila anak terpaksa harus menjalani proses pengadilan sebaiknya anak dijauhkan dari pengaruh dan implikasi negatif. Bentuk keadilan restoratif tersebut akan mendorong anak untuk bertanggung jawab atas perbuatannya. Selain itu anak mendapat kesempatan mengganti kesalahan dengan berbuat baik pada si korban dan memeliharahubungan dengan keluarga korban. Pada akhirnya anak diberi 
kesempatan untuk rekonsiliasi dan penyembuhan dalam masyarakat yang dirugikan oleh tindak pidananya.

\section{PENUTUP}

\section{Kesimpulan}

Dari hasil penelitian yang dilakukan maka dapat disimpulkan bahwa:

a. Dalam memutus perkara tindak pidana yang dilakukan oleh anak dibawah umur di Pengadilan Negeri Malili maka hakim mempertimbangkan hal-hal sebagai berikut:

1) Pertimbangan Yuridis, adalah pertimbangan hakim yang didasarkan pada fakta-fakta yuridis yang terungkap didalam persidangan dan oleh undang-undang telah ditetapkan sebagai hal yang harus dimuat di dalam putusan. Pada tulisan ini, yang dimaksudkan tersebut diantaranya adalah: Dakwaan jaksa penuntut umum, keterangan terdakwa dan saksi, barang-barang bukti, pasal-pasal dalam peraturan hukum pidana dan lain sebagainya.

2) Pertimbangan Non-Yuridis. Didalam memutus sebuah perkara dan mempertimbangkan layak tidaknya seseorang dijatuhi pidana seorang hakim didasarkan oleh keyakinan hakim dan tidak hanya berdasarkan bukti-bukti yang ada, tetapi juga mempertimbangkan keadaan-keadaan yang digolongkan sebagai pertimbangan yang bersifat nonyuridis seperti : latar belakang perbuatan terdakwa, akibat perbuatan terdakwa, kondisi diri terdakwa, keadaan sosial ekonomi terdakwa.

b. Tindakan lain Upaya-upaya serta tindakan-tindakan lain yang dapat dilakukan atau diusahakan dalam menyelesaikan perkara anak yang melakukan tindak pidana, tanpa harus menjalani hukuman penjara yakni : Menyerahkannya kembali kepada orang tua/Wali dan Mengikutsertakannya dalam program pendidikan, pembinaan, dan pembimbingan di instansi pemerintah atau LPKS.

\section{Saran}

Dari kesimpulan di atas, penulis menyarankan:

a. Dalam memutus perkara tindak pidana yang dilakukan oleh anak, hakim sebaiknya lebih mengedepankan kepentingan anak dan masa depan anak meskipun secara yuridis perbuatan anak telah memenuhi syarat materil dari suatu tindak pidana.

b. Tindakan-tindakan lain yang diberikan kepada anak yang melakukan tindak pidana selain pidana penjara diharapkan mampu memberikan efek jerah kepada anak dan merubah anak menajdi lebih baik, sehingga member masa depan yang lebih baik terhadap anak sebagai pelaku tindak pidana. 


\section{DAFTAR PUSTAKA}

Abintoro Prakoso, 2013, Pembaruan Sistem Peradilan Pidana Anak. Yogyakarta: Laksbang Grafika

Adami Chazawi, 2002. Pelajaran Hukum Pidana Bagian 2. Jakarta: PT. Raja Grafindo Persada.

Ammirudin dan Asikin, Zainal 2004, Pengantar Metode Penelitian Hukum, Jakarta: Raja Grafindo Persada.

Dellyana, Shanty, 1988, Wanita dan Anak di Mata Hukum, Yogyakarta: Liberty.

Leden Marpaung, 2005. Asas, Teori, Praktik Hukum Pidana. Jakarta : Sinar Grafika.

Maidin Gultom, 2010, Perlindungan Hukum Terhadap Anak, Bandung: Refika Aditama.

Nashriana, 2011, Perlindungan Hukum Pidana Bagi Anak Di Indonesia, Jakarta: Raja Grafindo.

Maidin Gultom. 2010. PERLINDUNGAN HUKUM TERHADAP ANAK DALAM SISTEM PERADILAN PIDANA ANAK DI INDONESIA. Refika Aditama: Bandung.

Marlina. 2009. Peradilan Pidana Anak di Indonesia Pengembangan Konsep Diversi dan Restorative Justice. PT Refika Aditama: Bandung.

Maulana Hassan Wadong. 2000. PENGANTAR ADVOKASI DAN HUKUM PERLINDUNGAN ANAK. PT Gramedia Widiasarana Indonesia: Jakarta.

M. Nasir Djamil. 2013. ANAK BUKAN UNTUK DIHUKUM (Catatan Pembahasan UU Sistem Peradilan Pidana Anak). Sinar Grafika: Jakarta.

Soetodjo, Wigiati, 2006, Hukum Pidana Anak, Bandung: Refika Aditama.

Ismantoro Dwi Yuwono. 2015. Penerapan Hukum Dalam Kasus Kekerasan Seksual Terhadap Anak, Pustaka Yustisia: Yogyakarta.

\section{Peraturan Perundangan-Undangan}

Kitab Undang-Undang Hukum Pidana

Undang-Undang Nomor 3 Tahun 1997 Tentang Pengadilan Anak

Undang-Undang Nomor 4 Tahun 1979 Tentang Kesejahteraan Anak

Undang-Undang Nomor 13 Tahun 2003 tentang Ketenagakerjaan

Undang-Undang Nomor 23 Tahun 2002 tentang Perlindungan Anak

Undang-Undang Nomor 11 Tahun 2012 tentang Sistem Peradilan Pidana Anak 